\title{
The limiting $\&$ facilitating factors for export through Textile, Chemical \& Pharmaceutical SMEs: In Indian perspective
}

\author{
By: Jaimin Vasa, \\ Chairman -MSME Committee, Gujarat Chamber of Commerce \& Industry, President-Gujarat Chemical \\ Association, Managing Director-Vasa Pharmachem Pvt Ltd.
}

\begin{abstract}
The SMEs are playing a strategic role in economic growth and development of the country through their contribution to the creation of wealth, employment and income generation.

The Textile \& Chemical Industries are the leading segment in the SME sector. For the Indian economy textiles \& chemical segments plays a major role. These segment of SMEs are exposed to the competitive pressures either directly from the market place or indirectly passed on from their higher ups in the chain. However, with SMEs dynamism, flexibility and innovative drive they are increasingly focusing on improved production methods, penetrative marketing strategies and management capabilities to continue and build up their operations. The Textiles exports consists of Fabrics, Ready-made garments, Cotton textiles, Textiles made from man-made fiber, Wool and Woolen goods, Silk, Handicrafts etc. Out of which man-made textiles and silk are showing the highest growth rate.

The Indian Chemical Industry comprises both small and large-scale units. The fiscal concessions granted to the small-scale sector in mid-eighties led to establishment of a large number of units in the Small Scale Industries (SSI) sector. Currently, the Indian Chemical industry is in the midst of a phase of major restructuring and consolidation. With the shift in emphasis on product innovation, brand building and environmental friendliness, this industry is increasingly moving towards greater customer orientation. Even though India enjoys an abundant supply of basic raw materials, it will have to build upon technical services and marketing capabilities to face global competition and increase its share of exports.

With the initiation of planned economy from 1951 and Government of India's subsequent industrial policy earmarked a special role for small-scale industries and medium scale industries in the Indian economy. Currently Textile \& Chemical SMEs are facing the challenge of increased competition on account of new open markets. In such a context the ability to export is becoming a critical factor in the development and long term survival of many SMEs.
\end{abstract}

\section{Overview Of Indian Textile Industry}

In India, the textile industry consist of mostly small-scale, non-integrated spinning, weaving, finishing, and apparel-making enterprises. Due to the policies on tax,labour and other regulations favored small-scale, labour-intensive enterprises. The textile sector is one of the largest employers in the country and within this sector, handloom weaving have a top rank. The textile sector generates more job opportunity from its own industry also opens up scopes for the other ancillary sectors. The textile industry largely depends upon the textile manufacturing and export. To disparity in domestic and international cotton prices, cotton exports couldn't pick up. The Textile segment has grown from a small-scale sector to multidimensional sector. Very few countries including India, which have a presence of complete supply chain, from natural and synthetic fibers right up to finished goods manufacturing. The industry holds vital importance in Indian economy too. After agriculture, only the handloom sector is the largest economic activity providing direct and indirect employment. This sector provide more than 30 lakh weavers. This sector contributes around $25 \%$ of the total cloth produced in the country and also contributes considerable amount of export income for the country. Over and above the employment potential, this sector provide large number of skilled and unskilled activities in the industry which makes the sector extremely important from the perspective of inclusive growth. Good availability of raw material along with the presence of complete manufacturing value chain which exists in an organized mill sector as well as decentralized sectors like handloom, power loom, silk, etc are the key features of Indian textiles industry. In the present economic environment where dependency on foreign capital and expertise is increasing all round, the handloom \& powerloom industries presents a sustainable model of economic activity that is not much energy-intensive and has low capital costs, as well as an extensive skill base.

\section{Overview of the Indian Chemical \& Pharma Industry}

The Indian Chemical Industry contribute significantly for the industrial and agricultural development of India and put forward connectivity for downstream industries. Indian chemical sector has grown rapidly since its early days of independence. Under chemical industries some of the other emerging sectors are petrochemical, 
agrochemical and pharmaceutical industries. Now, in the global map, Indian chemical industry holds a recognized position.

Indian chemical industry started to focus on marketing and promotion to achieve greater share in global chemical trade. The industry also made good effort and concentrated more on issues like brand building, export promotion and market development etc.

The Indian pharmaceutical industry is also growing every year. The Pharmaceutical industry in India fulfill maximum need of the country's demand for bulk drugs, drug intermediates, pharmaceutical formulations, chemicals, tablets, capsules, orals and injectables. There are approximately 300 large units and about 10000 Small Scale Units, which form the core of the pharmaceutical industry in India (including Central Public Sector Units).

India's pharmaceutical market is also growing. India ranks third in terms of manufacturing pharmaceutical products globally. According to McKinsey, the Pharmaceutical Market is ranked 14th in the world. By 2015 it is expected to reach top 10 in the world beating Brazil, Mexico, South Korea and Turkey. More importantly, the incremental market growth of US\$ 14billion over the next decade is likely to be the third largest among all markets. The US and China are expected to add US\$200bn and US\$ $23 \mathrm{bn}$ respectively.

\section{Historical view of Textile Export}

Indian textiles were exported to Britain on a large scale during the seventeenth century. The Indian cotton clothing was cheaper; it was also lighter and much more suitable for the hot Indian climate therefore, the heavier \& thick British clothing called broadcloth was very little demand. As a result EIC started importing Indian clothing into England. Once the first cargo of Indian cloths reached to Britain, the demand grew rapidly. In 1620 EIC had exported around 50,000 pieces painted and printed cotton. 1750s Indian textiles accounted for 60 percent of the total value of the East India Company's sales in London. In the 1690s, serious competition arises between the traditional woolen Manufactures and England's growing silk-weaving industry.

In fact, the cotton industry was probably first introduced into Britain by immigrants from the European continent. The Indian patterns and designs quickly became fashionable in Britain. They had exported large quantity of Indian cotton cloth to Britain in the seventeenth century which had a substantial effect on the domestic textile industry in Britain. Therefore, domestic textile producers in Britain forced to react, on the one hand lobbying for protection, and on the other hand imitating through printing on wool, linen and calico. In 1697, the British Commissioners of Trade and Plantations recommended measures to be taken against the British East India Company regarding the export from India. The Commissioners also urged to protect the domestic cloth industries from Indian textiles. As a result, in April 1700, the Parliament passed an act prohibiting the use or wearing of various types of Indian textiles such as finished silks or painted or dyed cotton cloths. But more expensive finely-woven cloth as well as the Plain, Calicoes, those not dyed was allowed to import from India, such calicoes after finishing at Britain they sold there.

In 1774, they repeal of the Act of Prohibitions on cotton goods and the Company's immediate response was to start the export and selling the Indian cloth to other countries. Indian clothing, however, remained popular and a large percentage of EIC imports during the $18^{\text {th }}$ centuries.

Since ancient times India well known for textile goods. During the colonial regime the traditional textile industry of India was virtually perished. However, in 1818, when the first textile mill was established at Fort Gloster near Calcutta the modern textile industry took birth in India. One of India's oldest industries in India is Textile Industry and has a formidable presence in the national economy. The main sectors of the Indian textile industry are Man-made Textiles, Cotton Textiles including Handlooms, Silk Textiles, Woollen Textiles, Handicrafts, Coir, Readymade Garments, and Jute. The Indian Textile Industry is huge and growing with presence of a number of national and international brands.

India has a varied and integrated fabric and apparel industries, and compared to China, Indian fabric and apparel industries has lower labour costs also the cotton prices in India was cheaper. These and other trends mean that India gained a comprehensive competitive edge over China. India able to target for sourcing fabrics and textiles across virtually all product categories. In our country Textile Industry has earned a unique place and this industry among one of the which were earliest to come into existence in India. In overall exports from India, the Textile exports played an important role. The Indian textiles industry export consists wide range of items like readymade garments, cotton textiles, handloom textiles, man-made fiber textiles, wool and woolen goods, silk, jute and handicrafts, including carpets. In the global exports of textiles, India ranked as the third largest exporter. India exports textiles to many countries. USA and the EU account for about two-third of India's total textiles exports. The other major export destinations include China, UAE, Sri Lanka, Saudi Arabia, Republic of Korea, Bangladesh, Turkey, Pakistan, Brazil, Hong Kong, Canada and Egypt.

Textiles and clothing worth US \$26.82 billion were exported during 2010-11 as against US\$ 22.41 billion during 2009-10, registering an increase of about 19.66 per cent. During April-November 2011, exports of textiles and clothing were of the order of US\$ 19.78 billion as against US\$15.86 billion during the same period 
of 2010, registering a considerable growth of 24.73 per cent. In respect of global exports of clothing, India ranked sixth largest exporter as per the World trade Organization (WTO) trailing behind Turkey, Bangladesh, Hong Kong, EU-27, and China. In respect of global exports of textiles, India ranked third, trailing EU-27 and China

\section{Historical view of Chemical \& Pharmaceutical Export}

There is a global demand for Indian chemical products due to their high quality and competitive pricing. India's expertise in developing low cost yet high end chemical products is the key growth driver for Indian chemical exports. To the global chemical industry Asia's contribution growing significantly and India emerges as one of the focus destinations for chemical companies worldwide. Share of chemical industry in national exports is around $11 \%$. In terms of volume, India is the third-largest producer of chemicals in Asia, after China and Japan. Six major chemicals produced in India are Methanol, Aniline, Alkyle Amines and its derivatives like Formaldehyde, Acetic Acid and Phenol, contributing to nearly 2/3rd of Indian basic organic chemical industry. The balance $1 / 3$ rd of the organic chemical consumption in the country is accounted for by other wide variety of chemicals.

Specialty chemicals are defined as a "group of relatively high value, low volume chemicals known for their end use applications and/ or performance enhancing properties." To increase exports in the Chemical Sectors, efforts need to be made to improve contacts with end users and trading centers in Asia, Europe, South Africa and Latin America as they are a vital link between the supplier and the local consumers. Both the industry and govt. can play a vital role in promoting Indian products as a brand 'Made in India' by conducting events for increasing awareness among foreign buyers. Trade delegations are also an integral part of global trade. It is of paramount importance to send delegations abroad to get better understanding of the markets and assess export potential.

The Ministry of Chemicals \& Fertilizers was created a separate Department for Pharmaceuticals on 01.07.2008 to provide greater focus for the growth of the Pharmaceuticals industry with the objective of Formulate Scheme/ Project for promoting environmentally sustainable development of Pharmaceutical Industry as well as make India as the largest global provider of quality medicines at reasonable prices. The other important focus area for the Department of Pharmaceuticals is promotion of Indian pharma exports.

The Indian pharmaceutical industry positioned among the top five countries by volume (production) and accounts for about $10 \%$ of global production. Some of the main factors supporting these growth are low cost of skilled manpower and innovation. The Indian pharmaceutical industry's growth has been mainly due to exports. Various pharmaceutical products are exported by India to various countries with a sizable share especially in the advanced regulated markets of the US and Western Europe. Also India exports drug intermediates, active pharmaceutical ingredients, finished dosage formulations, bio-pharmaceuticals and clinical services to various parts of the world.

\section{Limiting factors for export}

SMEs are currently facing the challenge of increased competition as a result of new open markets. In such a context the ability to export is becoming a critical factor in the development and long term survival of many SMEs. SMEs can play a major role in the exporting process, if they are placed in an enabling environment and provided with a proper incentives scheme.

Marketing knowledge and information are two of export problems which revolve around, lack of knowledge of foreign markets, business practices, and competition; and lack of management to generate foreign sales. Also lack of knowledge to locate foreign opportunities and promising markets is supposed to be a major obstacle in exporting of SMEs.

\section{Facilitating factors for export}

Due to devaluation of rupee against the dollar brought the Indian textile sector including the apparel export is getting advantage and will be back on the global map. According to the report, the Textile and Apparel industry hopes their exports will be higher by 15-20 per cent in 2013-14. Textile export orders in the last few months have started to pick up due to the overall better response in the US and the Euro zone. Also many textile industries are now shifting their focus to other non-traditional countries like Japan, Latin America and Australia to increase their exports.

India is a fast emerging market with more than 1.21 billion population with good purchasing power. These factor is good for the Indian textile industry in the long run. Even though the global economic crisis has already affected the export oriented sector such as textiles \& clothing, as long as Indian economy is growing, textile industry would grow provided it takes competition and innovation seriously. Recent trends in competing countries, particularly China, in the area of mass and labour intensive sector such as Textiles and Garments etc., show that due to the wage increases as well as other government policy changes in those countries the investors 
are looking for alternate locations. This development provides an tremendous opportunity for India to attract companies which are looking for alternate source. Coordinated efforts to attract these investments need to be put in place for attracting the importing countries. The Textile Policy introduced by the Government of India in the year 1985 indicated a new beginning for the textile industry which focused on the deep-rooted structural weaknesses. Due the 1990 reforms further enhanced the textile industry. When the textile industry was delicensed and reforms on fiscal and export front were pursued and as a result, India's Textile export increased significantly.

As per the recommendation of $9^{\text {th }}$ Five Year Plan Working Group Report on Drugs and Pharmaceuticals, Pharmaceutical Department had formed Pharmexcil. In view of this, the Department continuously interacts with Pharmexcil in their work areas. The role of Pharmexcil is for facilitation of exports of Pharmaceutical products. As a major area of work, Pharmexcil also holds Buyers/Sellers meets and compiles detailed data base on pharma exports and problems in exporting pharma products. An important focus area for the Department of Pharmaceuticals is promotion of Indian pharma exports. The improvement in sales growth will be largely motivated by higher realization of export oriented Pharma companies. The sector generates around 40 percent of its sales from exports.

\section{Economic Reforms}

The economic reforms of 1991 had a significant impact on the domestic chemical industry. The Chemical \& Pharmaceutical SMEs in India has great growth potential and witnessed strong demand in the last decade and this is expected to continue. Share of industry in national exports is around $11 \%$. Chemical industries are leveraging the significant export potential of country, after meeting the domestic demand, in segments like pharmaceuticals, agrochemicals, dyestuffs \& specialty chemicals. Indian chemical industry exports dyes, pesticides and specialty chemicals to the developed world and to the developing countries and contributes significantly to the foreign exchange basket of the country. The fiscal concessions granted to small scale sector in mid-eighties led to the establishment of a large number of units in the Small Scale Industries (SSI) sector.

\section{Government Policies for increasing the SMEs' export}

The formation and development of a business-friendly policies enabling SMEs to start exporting, as well as help them to consolidate the activities of exporting.

In the age of globalization, Industries especially SMEs have to continually innovate new products and have to upgrade the quality of existing goods and services. To promote standardization and facilitate the international exchange of goods and services, and cooperation in fields such as intellectual, scientific, technological and economic activities the Quality Management theory has been formulated. The ISO 9000 standards series prescribes good quality practices. The implementation of ISO 9000 reduces faulty goods, and improves the performance of workers. It also enables easy accessible, traceable and auditable work procedure. ISO standards facilitate trade between countries and with the provision of reimbursement of 75 per cent of costs by the government for acquiring the ISO Certification helped greater competitive advantage and greater opportunity for SMEs to increase their export.

In a highly competitive globalising world Indian SMEs require business advisory services to enhance their international competitiveness. Therefore, Export-Import bank act 1981pased in the parliament in September 1981 by Government of India. Since its commencement, Exim Bank of India has been acting as a channel and a key player in encouraging the cross border trade and investment. Commencing operations as a purveyor of export credit, like other Export Credit Agencies in the world, Exim Bank of India has, over the period, evolved into an institution that plays a major role in partnering Indian industries, particularly the Small and Medium Enterprises, in their globalisation efforts, through a wide range of products and services offered at all stages of the business cycle, starting from import of technology and export product development to export production, export marketing, pre-shipment and post-shipment and overseas investment.

The SMEs find the services of reputed national and international consultants as not cost effective and often, not adequately focused. Recognising this knowledge gap, Exim Bank of India has been endeavoring to provide a suite of services to its SME clients. These include providing business leads, hand holding during the process of winning an export contract and thus assisting the generation of export business on success fee basis, countries/ sector information dissemination, capacity building in niche areas such as quality, safety, export marketing, etc. and financial advisory services such as loan syndication, etc.

The Industrial Policy of 1991 represents a conscious shift from the traditional policy of control and regulation to a policy paradigm fostering liberalisation. The implementation of liberalisation policy meant that most of the medium and large industrial units would no longer need licenses. Full foreign ownership would henceforth be possible in export-oriented enterprises. Capital goods would be imported free from restrictions. Foreign equity participation was also encouraged. The openness that came along with the experience of 
economic reform since 1991 has brought in its train a whole raft of changes that have established India as a key player in the global economy.

SMEs were, however, hard hit by the Government's recourse to liberalisation policy to the extent that they would hardly survive the competitive pressure unleashed by liberalisation without provision of support. Thus, for instance, the 2006 budget of the Indian Government introduced a special provision for improving credit flow for SMEs. The Reserve Bank of India (RBI) also has had to revise the definition of SMEs1 in order to enable debt-restructuring benefit. Thus enterprises with capital up to Rs. 10 million were treated as small scale industries (SSIs), and those with capital over Rs. 10 million and up to 100 million as medium enterprises.

As per the recommendation of 9th Five Year Plan Working Group Report on Drugs and Pharmaceuticals, the Department had played a pivotal role in the formation of Pharmexcil. Accordingly, the Department constantly interacts with Pharmexcil in their work areas. The Pharmexcil role is facilitating exports of Drugs, Pharmaceuticals, Biotechnology products, Herbal medicines and Diagnostics etc. Pharmexcil is authorised to issue Registration-cum-Membership Certificate (RCMC) which is one of the requirements for the importers and exporters of commodities. In addition to this, Pharmexcil is concerned with giving export thrust to the various products through visits of delegations to various markets abroad, organizing of seminars, workshops and exhibitions. As a major area of work, Pharmexcil also holds Buyers/Sellers meets and compiles detailed data base on pharma exports and problems in exporting pharma products. The sector had made around 40 percent of its sales from exports. The decline in the rupees is resulted in higher export realisations, this have been enhanced the over all growth of the sector. The improvement in sales growth have been largely from the higher realization of export oriented Pharm companies.

\section{Conclusion:-}

Export is considered one way of motivating factor for growth of SMEs, which will gradually improve the quality standards of products manufactured by Textile, Chemical \& Pharmaceutical in the SME sector. Also it will capture more global shares.Increasing the contribution of small and medium enterprises of Textile, Chemical \& Pharmaceutical in total exports of India is vital to India's future economic growth. A sharp depreciation in the rupees is expected to result in higher export realisations, which will enhance the over all growth of the Textile, Chemical \& Pharmaceutical SMEs.

\section{References:-}

[1]. India biznews: December 19, $2012 \mathrm{http} / /$ www.indiabiznews.com/ P.1

[2]. http://www.paulrittman.com/EastIndiaCompany.pdf P.4

[3]. Cotton textiles and the great divergence: lancashire, India and shifting competitiveadvantage, 1600-1850 Stephen Broadberry and Bishnupriya Gupta p. 15

[4]. Sources: 1665-1759: Chaudhuri (1978: 540-545); Morineau (1999: 273-274).1771- 1794: Milburn [1813, vol.2: 234].

[5]. http://www.indianmirror.com/indian-industries/2012/textile-2012.html "Indian textile at A Glance in $2011-2012$ " p.1

[6]. Textile exports on upswing, by Sharleen D'souza, Mumbai July 4, $2013 \quad$ (http://www.businessstandard.com/article/markets/textile-exports-on- upswing- 113070401085_1.html)

[7]. Productivity \& Competitiveness of Indian Manufacturing-Textile \& Garments Sector final report submitted to National Manufacturing competitive councile, New Delhi , 2010 p.3

[8]. http://chemicals.nic.in/DNCP_2012.pdf - "Department of Chemical \& Petrochemicals Annual Report 2011-2012” p. 5

[9]. http://pharmaceuticals.gov.in/annualreport2012.pdf - p.12\&13

[10]. http://www.eximbankindia.com/sme.asp on 1.8.2013

[11]. Enhancing the competitiveness of SMEs through industrial clusters: TheIndian experience by S. Venkataramanaiah and S.P. Parashar Indian Institute of Management Indore, India p. 3

[12]. Ministry of Chemicals \& Fertilizers Department of Pharmaceuticals annual report 2011-12-p.7,p8,p10 